УДК 796.011 .3

\title{
ТЕОРЕТИЧНІ ТА МЕТОДИЧНІ ОСНОВИ ФОРМУВАННЯ ЗДОРОВ'ЯЗБЕРІГАЛЬНОЇ КОМПЕТЕНЦІЇ СТУДЕНТІВ ЗАКЛАДІВ ВИЩОЇ ОСВІТИ
}

\author{
Олена Іщук ${ }^{1}$, Анатолій Цьось² \\ ${ }^{1}$ Східноєвропейський національний університет імені Лесі Українки, Луцьк, Україна, \\ olenkaishuk@gmail.com \\ ${ }^{2}$ Гуманістично-природничий університет імені Яна Длугоша в Ченстохові, Польща, \\ a.tsos@ajd.czest.pl
}

https://doi.org/10.29038/2220-7481-2018-04-21-28

\begin{abstract}
Анотації
Актуальність. Ефективним способом зміцнення здоров'я молоді $є$ організація навчально-виховного процесу на основі компетентнісного підходу, який забезпечує фізичне й психічне благополуччя індивіда. Проте в науковій літературі недостатньо аргументовано відомості щодо складників та методики формування здоров'язберігальної компетенції студентів закладів вищої освіти. Мета дослідження - розробити методику формування здоров'язберігальної компетенції студентів закладів вищої освіти й перевірити їі ефективність. Методи досліджения - аналіз психолого-педагогічної літератури, систематизація інформації, педагогічне тестування, анкетування, педагогічний експеримент, педагогічне спостереження, математична статистика. На різних етапах дослідження взяли участь 480 студентів. Результати. Здоров'язберігальна компетенція - це система цінностей, взаємозв'язаних і взаємозумовлених знань, умінь і навиків, рівня фізичного стану, які забезпечують високий рівень здоров'язберігальної діяльності. В основу здоров'язберігальної компетенції покладено ціннісний, когнітивний та діяльнісний компоненти. Ціннісний передбачає наявність у студентів стійкого інтересу й мотивації до здоров'язберігальної діяльності, активне ставлення до здорового способу життя, здатність до рефлексії та саморегуляції поведінки й емоційних станів. Когнітивний компонент сприяє сформованості в студентів системи знань, умінь і навичок, що забезпечують міцний стан здоров'я. Діяльнісний компонент характеризується систематичністю занять фізичними вправами; активністю в здоров'язберігальній діяльності; використанням сформованих знань, умінь, навичок у самостійній роботі студентів із фізичного виховання. Діяльнісний компонент забезпечує успішне виконання здоров'язберігальної діяльності й вирізняється належним рівнем фізичного стану та стану здоров'я. Висновки. Формування здоров'язберігальної компетенції - це цілеспрямований і структурований процес, який охоплює формування мотивації до здоров'язберігальної діяльності й систематичної рухової активності, засвоєння теоретичних знань і практичних умінь, підвищення фізичної підготовленості та функціональних можливостей.
\end{abstract}

Ключові слова: здоров'язберігальна компетенція, фізичне виховання, здоров'я, студенти, методика.

Елена Ищук, Анатолий Цёсь. Теоретические и методические основы формирования здоровьесберегающей компетенции студентов высших учебных заведений. Актуальность. Эффективным способом укрепления здоровья молодежи является организация учебно-воспитательного процесса на основе компетентностного подхода, который обеспечивает физическое и психическое благополучие индивида. Однако в научной литературе недостаточно аргументированы сведения о составляющих и методике формирования здоровьесберегающей компетенции студентов высших учебных заведений. Цель исследования - разработать методику формирования здоровьесберегающей компетенции студентов высших учебных заведений и проверить ее эффективность. Методы исследования - анализ психолого-педагогической литературы, систематизация информации, педагогическое тестирование, анкетирование, педагогический эксперимент, педагогическое наблюдение, математическая статистика. На разных этапах исследования приняли участие 480 студентов. Результаты. Здоровьесберегающая компетенция - это система ценностей, взаимосвязанных и взаимообусловленных знаний, умений и навыков, физическое состояние, что обеспечивают высокий уровень здоровьесберегающей деятельности, признание здоровья важнейшей ценностью человеческого бытия. В основе здоровьесберегающей компетенции лежат ценностный, когнитивный и деятельностный компоненты. Ценностный предусматривает наличие у студентов устойчивого интереса и мотивации к здоровьесберегающей деятельности, активное отношение к здоровому образу жизни, способность к рефлексии, саморегуляции поведения и эмоциональных состояний. Когнитивный компонент определяет сформированность у студентов системы знаний, умений и навыков, которые обеспечивают крепкое состояние здоровья. Деятельностный компонент 
характеризуется систематичностью занятий физическими упражнениями; активностью в здоровьесберегающей деятельности; использованием сформированных знаний, умений и навыков 21-28 )ятельной работе студентов из физического воспитания. Деятельностный компонент обеспечивает успешное выполнение здоровьесберегающей деятельности и отличается должным уровнем физического состояния и здоровья. Выводы. Формирование здоровьесберегающей компетенции - это целенаправленный и структурированный процесс, который охватывает формирование мотивации к здоровьесберегающей деятельности и систематической двигательной активности, усвоение теоретических знаний и практических умений, повышение физической подготовленности и функциональных возможностей.

Ключевые слова: здоровьесберегающая компетенция, физическое воспитание, здоровье, студенты, методика.

Olena Ishchuk, Anatolii Tsos. Theoretical and Methodological Basics of Students' Health Retaining Competence Formation of Higher Educational Institutions. Topicality. An effective way to improve the youth health is to organize an educational process based on a competent approach that ensures the physical and mental well-being of the individual. However, the scientific literature does not adequately substantiate the information on the components and methods of students' health retaining competence formation of higher educational institutions. The purpose of the research is to develop a methodology for the formation of students' health retaining competence of higher educational institutions and to check its effectiveness. Methods of the research are the analysis of psychological and pedagogical literature, systematization of information, pedagogical testing, questionnaires, pedagogical experiment, pedagogical observation, and mathematical statistics. 480 students were participated at the various stages of the research. Results. Health retaining competence is a system of values, interconnected and mutual influenced knowledge, skills and abilities, level of physical condition, which provide a high level of healthcare activity. The value, cognitive and activity components lay at the heart of health retaining competence. The valuable component of health retaining competence implies the presence at students of stable interest and motivation to health competence activity, an active attitude to a healthy lifestyle, the ability to reflection and self-regulation of behavior and emotional states. The cognitive component promotes the formation of a system of knowledge, skills that provide a strong state of health. The active component is characterized by systematic physical exercises; the activity in heath retaining activity; using the existing knowledge, skills at students` individual work in the field of physical education. The active component ensures the successful performance of health retaining activity and it is characterized by an adequate level of physical condition and state of health. Conclusions. The formation of health retaining competence is a purposeful and structured process that involves the formation of motivation to health retaining activity and systematic motor activity, assimilation of theoretical knowledge and practical skills, increase of physical preparedness and functionality.

Key words: health retaining competence, physical education, health, students, methodology.

Вступ. Проблему здоров'я людини в широкому розумінні світова спільнота відносить до кола глобальних. Серед причин зниження стану здоров’я - соціально-економічні й екологічні чинники, неефективна стратегія охорони здоров'я й недоліки в системі освіти. Також незаперечний і той факт, що майбутнє кожної країни, їі політичний, економічний та культурний рівні залежать від того, наскільки вона створює сприятливі умови для повноцінного розвитку й щасливого життя молоді.

Аналіз вітчизняних і зарубіжних наукових джерел дав змогу визначити значний досвід, накопичений у теорії й практиці збереження та зміцнення здоров’я $[6 ; 10 ; 17 ; 20 ; 22 ; 23]$. У наукових працях обгрунтовано методики формування культури здоров'я, визначено основні умови створення здоров'язберігального освітнього середовищ, розроблено вимоги до здоров'язберігальної діяльності [1; 12; 15; 21], рекомендовано програми зміцнення здоров'я молоді засобами фізичної активності $[4 ; 8 ; 11 ; 14 ; 16 ; 18 ; 19]$. Результатом навчальної діяльності є формування здоров’язберігальної компетенції [2].

У наукових працях [2; 7; 9; 13; 17] констатовано, що ефективним способом зміцнення та збереження здоров'я студентської молоді є організація навчально-виховного процесу на основі компетентнісного підходу, який створює стійку мотивацію до здоров'язбереження, самовизначення особистості в здоровому способі життя, озброює засобами й методами, що забезпечують фізичне й психічне благополуччя індивіда. Реалізація цього підходу передбачає формування під час навчання ключових компетенцій, зокрема здоров'язберігальної компетенції. Проте в сучасній науковій літературі недостатньо аргументовано відомості щодо складників і методики формування здоров'язберігальної компетенції студентів вищих навчальних закладів.

Мета дослідження - розробити методику формування здоров’язберігальної компетенції студентів закладів вищої освіти та перевірити їі ефективність.

Матеріал і методи дослідження. Для виконання сформованих завдань застосовано систему методів дослідження. Теоретичні - вивчення психолого-педагогічних і медико-біологічних літературних джерел із проблеми здоров’я та фізичного виховання в системі вищої освіти (дали змогу систематизувати 
базові поняття 3 досліджуваної проблеми й окреслити сутність здоров'язберігальної компетенції студентів). Емпіричні - спостереження за навчально-виховною діяльністю, аналіз іiі результатів, анкетування, тестування, педагогічний експеримент (уможливили вияв стану та особливостей формування здоров'язберігальної компетенції студентів, апробацію методики формування здоров'язберігальної компетенції студентів вищих навчальних закладів у процесі фізичного виховання). Статистичні - сприяли якіснокількісному аналізу експериментальних даних, перевірці достовірності одержаних результатів.

Дослідницько-експериментальну роботу здійснювали на базі Східноєвропейського національного університету імені Лесі Українки, Луцького національного технічного університету. На різних етапах дослідження взяли участь 480 студентів. Для перевірки ефективності розробленої методики формування здоров'язберігальної компетенції проводили педагогічний експеримент зі студентками Східноєвропейського національного університету імені Лесі Українки. Усього задіяно 247 студенток, із яких 125 - експериментальна група, а 122 - контрольна.

Результати дослідження. Грунтуючись на результатах наукових досліджень $[3 ; 5 ; 10 ; 17]$ та власних даних, визначено, що здоров'язберігальна компетенція - це система цінностей, взаємозв'язаних і взаємозумовлених знань, умінь і навиків, рівня фізичного стану, що забезпечують високий рівень здоров'язберігальної діяльності, визнання здоров'я найважливішою цінністю людського буття.

Отримані дані дали змогу обгрунтувати основні компоненти (ціннісний, когнітивний, діяльнісний) здоров’язберігальної компетентності студентів (рис. 1).

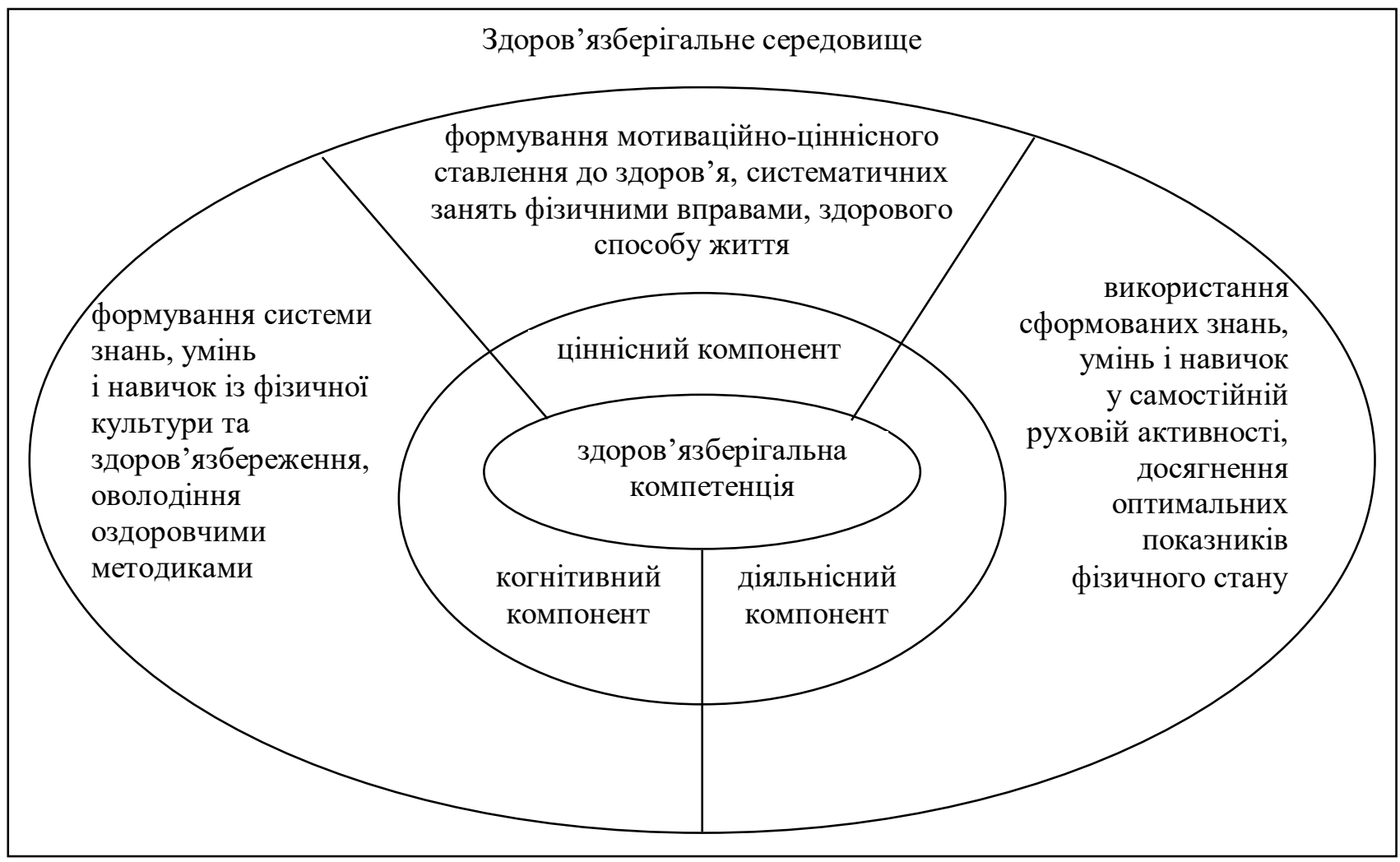

Рис. 1. Основні компоненти здоров'язберігальної компетениії

Ціннісний компонент здоров'язберігальної компетенції передбачає наявність у студентів стійкого інтересу та мотивації до здоров'язберігальної діяльності, активне ставлення до здорового способу життя, здатність до рефлексії та саморегуляції поведінки й емоційних станів.

Дослідження свідчить, що рівень інтересу до фізичної культури в студенток університету відповідає середньому показнику. Під час навчання простежуємо тенденцію до зниження інтересу в молоді й появи таких, у яких він відсутній. Отримання добрих оцінок - один із головних мотивів у студенток до занять із фізичного виховання в університеті. Більшість дівчат обмежують свою рухову активність лише обов'язковими навчальними заняттями з фізичного виховання.

За окремими психологічними показниками спостерігаємо негативну тенденцію розвитку в студентів таких станів, які можуть призвести до погіршення рівня здоров'я або становлять пряму загрозу йому. Зокрема, за шкалою фрустрації осіб, які не мають високої самооцінки, стійкі до невдач і не бояться 
труднощів, ми виявили 50 \% серед студентів першого курсу навчання, 66,6 \% - другого, 42,6 \% - третього й 59,6 \% - четвертого. Середній рівень фрустрації властивий дл21-28 “льшої кількості студенток першого курсу навчання $(47,9 \%)$, другого $(27,7 \%)$, третього $(53,7 \%)$ та четвертого $(40,4 \%)$. За отриманими результатами методики САН виявлено, що за шкалою «Самопочуття» сприятливий стан спостерігаємо в 30,3 \% опитаних студентів, 29,4 \% - нормальний і 62,3 \% - несприятливий. За шкалою «Активність» розподіл студентів за станом такий: 29,4\% - сприятливий, $24 \%$ - середній та 34,6 \% несприятливий. За шкалою «Настрій» 35 \% студенток належать до таких, які мають чудовий настрій, $29,4 \%$ - нормальний і 35,6 \% - поганий.

Когнітивний компонент передбачає сформованість у студентів системи знань, умінь і навичок, що забезпечують міцний стан здоров'я. Результати дослідження засвідчують низький рівень теоретичної підготовленості студенток вищого навчального закладу з основних розділів знань, які необхідні для формування достатнього рівня здоров'язберігальної компетенції.

Діяльнісний компонент характеризується систематичністю занять фізичними вправами; активністю в здоров'язберігальній діяльності; використанням сформованих знань, умінь, навичок у самостійній роботі студентів із фізичного виховання. Діяльнісний компонент забезпечує успішне виконання здоров'язберігальної діяльності й вирізняється належним рівнем фізичного стану та здоров 'я. Фізичний стан - це інтегрована ознака життєдіяльності організму, що визначається фізичним розвитком, фізичною підготовленістю, функціональними можливостями організму й станом здоров'я людини.

Результати дослідження фізичного розвитку дівчат демонструють, що довжина тіла становить 162,4-165,6 см, маса - 52,2-56,4 см, окружність грудної клітки в стані спокою - 81,5-87,3 см, на вдиху - 84,8-91,0 см, на видиху - 79,3-85,7 см. Антропометричні величини загалом перебувають у межах вікових норм. Показники фізичного розвитку студенток практично не змінюються, що зумовлено фізіологічними механізмами вікового періоду.

Одержані дані дають підставу стверджувати, що середньогрупові показники фізичної підготовленості студенток низькі. Зазначимо, що з першого до другого курсу навчання в дівчат простежуємо тенденцію до підвищення фізичної підготовленості на 3,8-18,5 \% (залежно від курсу навчання). Потім відбувається певна стабілізація результатів із наступним їх зниженням (до 28,4 \%) на четвертому курсі навчання.

Середньогрупові показники діастолічного й систолічного артеріального тиску студенток університету перебувають у межах вікових норм. Водночас підвищений артеріальний систолічний тиск мають $19 \%$ першокурсниць, 12,82 \% - друго-, 5,7 \% - третьо- та 24,5\% - четвертокурсників. Частота серцевих скорочень у студенток - у межах 77,4-87 уд./хв. Проте значна кількість дівчат має тахікардію (на третьому, четвертому курсах навчання таких понад 50 \%).

Отже, ціннісний, когнітивний та діяльнісний складники здоров'язберігальної компетенції студенток не повною мірою відповідають вимогам повноцінної здоров'язберігальної діяльності, що потребує додаткового наукового пошуку.

Дискусія. На основі аналізу літературних джерел, практики роботи вищих навчальних закладів, а також системного підходу як методологічної основи дослідження розроблено методику формування здоров'язберігальної компетенції студентів, що охоплює дотримання визначеної мети, завдань, принципів, педагогічних умов, методів, засобів, форм й етапів навчання (рис. 2).

Мета формування здоров'язберігальної компетенції передбачає розвиток у студенток особистісних якостей, спеціальних знань, умінь і навичок, фізичної активності, що забезпечують високий рівень життєдіяльності. Ефективне формування здоров'язберігальної компетенції може відбуватися лише в умовах здоров'язберігальної діяльності, яку розглядають як специфічну форму людської активності, що відбувається в умовах здорового способу життя. В основу розробленої методики покладено формування ціннісного, когнітивного та діяльнісного компонентів здоров'язберігальної компетенції студенток.

До головних педагогічних умов формування в студентів здоров'язберігальної компетенції належать особистісно-діяльнісний підхід, безперервність навчально-тренувального процесу, орієнтація на самовиховання й саморозвиток, міждисциплінарна інтеграція, створення атмосфери співпраці та взаємонавчання.

Формування здоров'язберігальної компетенції студентів здійснюють протягом трьох етапів підготовчого, основного й узагальнювального. На першому етапі - формування мотиваційно-ціннісного ставлення до фізичної активності - у респондентів виховують розуміння значення самостійних занять фізичними вправами, стійкий інтерес і мотивацію до виконання фізичних вправ та здорового способу життя. На другому створюють систему знань, умінь і навичок із фізичної культури, формують уміння самостійного виконання фізичних вправ, побудови програм оздоровчого тренування. Третій етап передбачає 
використання сформованих знань, умінь і навичок у самостійній руховій активності, залучення, засвоєння правил та технологій оздоровчого тренування, накопичення практичного досвіду виконання фізичних вправ.

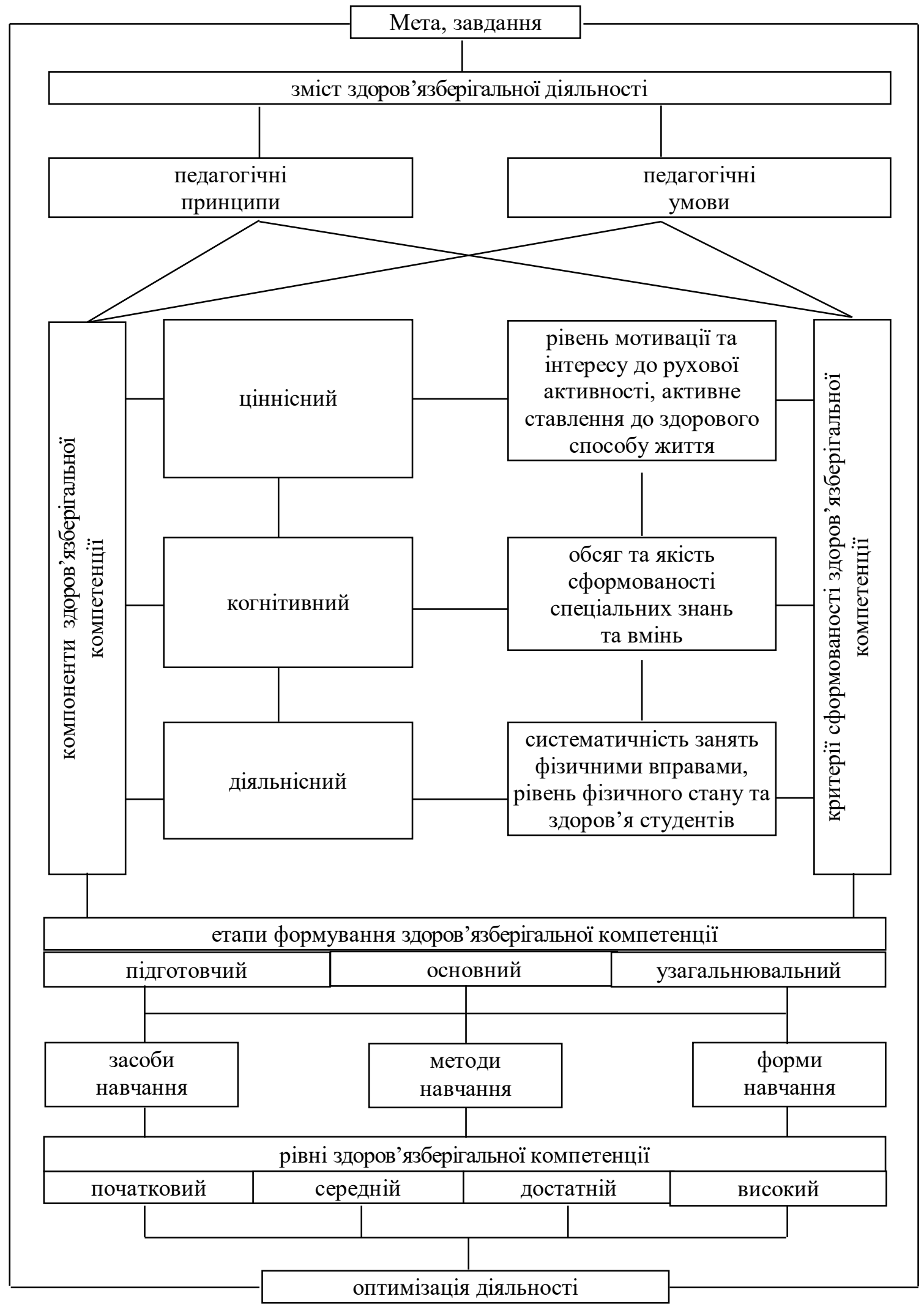

Рис. 2. Структура методики формування здоров'язберігальної компетениії 
Ефективність реалізації завдань здоров'язберігальної компетенції залежала безпосередньо від ефективної педагогічної взаємодії викладача й студентів, що ст21-28 та ситуацію взаємодовіри, високу емоційну активність занять.

Апробація розробленої методики в практиці фізичного виховання студентів засвідчила іï високу ефективність, що підтверджується зростанням показників здоров'язберігальної компетенції, підвищенням кількості осіб, котрі самостійно виконували фізичні вправи до 78 \%, підвищенням рівня фізичної підготовленості за всіма руховими тестами.

Висновки. Здоров'язберігальна компетенція - це система цінностей, взаємозв'язаних i взаємозумовлених знань, умінь і навиків, рівня фізичного стану, які забезпечують високий рівень здоров'язберігальної діяльності, визнання здоров'я найважливішою цінністю людського буття.

В основу здоров'язберігальної компетенції покладено ціннісний, когнітивний і діяльнісний компоненти. Ціннісний компонент здоров'язберігальної компетенції передбачає наявність у студентів стійкого інтересу та мотивації до здоров'язберігальної діяльності. Когнітивний компонент сприяє сформованості в студентів системи знань, умінь і навичок, що забезпечують міцний стан здоров'я. Діяльнісний компонент характеризується систематичністю занять фізичними вправами, використанням сформованих знань у самостійній роботі. Ціннісний, когнітивний і діяльнісний складники здоров'язберігальної компетенції студенток не повною мірою відповідають вимогам повноцінної здоров'язберігальній діяльності.

Формування здоров'язберігальної компетенції - це цілеспрямований і структурований процес, який охоплює формування мотивації до здоров'язберігальної діяльності й систематичної рухової активності, засвоєння теоретичних знань і практичних умінь, підвищення фізичної підготовленості та функціональних можливостей. Методика формування здоров'язберігальної компетенції розроблена на основі аналізу літературних джерел, практики роботи вищих навчальних закладів, а також системного підходу як методологічної основи дослідження, що охоплює взаємозв'язок усіх компонентів навчального процесу за дотримання визначеної мети, завдань, принципів, педагогічних умов, методів, засобів, форм й етапів навчання. В основу розробленої методики покладено формування мотиваційного, когнітивного та діяльнісного компонентів здоров'язберігальної компетенції.

\section{Джерела та література}

1. Андрійчук О., Шевчук А., Самчук О., Хомич А. Особливості фізичного й психологічного компонентів здоров'я студентів залежно від їхніх навчальних досягнень. Фізичне виховання, спорт $i$ культура здоров'я у сучасному суспільстві: зб. наук. праць Східноєвроп. нац. ун-ту ім. Лесі Українки. Луцьк, 2015. № 3 (31). C. $96-104$.

2. Бєлікова Н. О. 3 досвіду використання інтерактивних методів навчання у професійній підготовці майбутніх фахівців з фізичного виховання та спорту. Сучасні інформаційні технології та інноваиійні методики навчання в підготовиі фахівиів: методологія, теорія, досвід, проблеми: зб. наук. праць. Вип. 37. Київ; Вінниця: ТОВ фірма «Планер», 2014. С. 348-353.

3. Деделюк Н. А, Ковальчук Н. М., Ващук Л. М., Томащук О. Г., Санюк В. І., Савчук С. А. Модель організації спортивно-оздоровчої діяльності студентів вищих навчальних закладів. Фізичне виховання, спорт $i$ культура здоров'я у сучасному суспільстві: зб. наук. праць Східноєвроп. нац. ун-ту ім. Лесі Українки. Луцьк, 2018. № 1 (41). С. 29-35.

4. Захожий В. В., Сапожник О. А. Дозування фізичних навантажень для самостійних занять фізичними вправами студентів. Фізичне виховання, спорт, і культура здоров'я у сучасному суспільстві: зб. наук. праць Волин. нац. ун-ту ім. Лесі Українки. 2009. № 2 (6). С. 39-42.

5. Иващенко Л. Я., Благий А. Л., Усачев Ю. А. Программирование занятий оздоровительным фитнесом. Киев: Наук. свит, 2008. 198 с.

6. Індика С. Я. Роль освітньої програми у реабілітації хворих після інфаркту міокарда. Науковий часопис Наиіонального педагогічного університету імені М. П. Драгоманова. Серія № 15: Науково-педагогічні проблеми фізичної культури (фізична культура і спорт): [зб. наук. праць]. Київ: Вид-во НПУ ім. М. П. Драгоманова, 2015. Серія 15. Вип. 3К2 (57). 15. С. 145-147.

7. Круцевич Т. Ю., Безверхня Г. В. Рекреація у фізичній культурі різних груп населення. Київ: Олімп. літ., 2010. $248 \mathrm{c}$.

8. Митчик О. П., Сапожник О. А. Рівень інтересу до фізичної культури й спорту в студенток ВНЗ. Фізичне виховання, спорт, і культура здоров'я у сучасному суспільстві: зб. наук. праць Волин. нац. унту ім. Лесі Українки. 2011. № 1 (13). С. 40-43.

9. Мічуда Ю. П. Проблеми вдосконалення механізму державного управління сферою фізичної культури і спорту в Україні. Збірник наукових праџь Волинського держсвного університету. Т.1. Луцьк, 2002. C. $26-28$.

10. Муравов И. В. Оздоровительные аспекты физической культуры и спорта. Киев: Здоровья, 1989. 124 с. 
11. Навроцький Е., Пантік В. Удосконалення силових якостей студентів засобами атлетичної гімнастики. Фізичне виховання, спорт і культура здоров'я у сучасному суспільстві: зб. наук. праць. Луцьк, 2013. № 2(22). C. 47-51.

12. Пантік В. В., Навроцький Е. М. Вплив систематичних занять фізичними вправами на системи організму та рівень соматичного здоров'я людини. Науковий вісник Волинського держсвного університету імені Лесі Украӥнки. 2004. № 4. С.195-199.

13. Ровний А. С. Ровний В. А., Ровна О. О. Фізіологія рухової активності. Харків, 2014. 344 с.

14. Рода О. Б., Маріонда I. І. Тенденції наукових досліджень спортсменок в аспекті статевих особливостей. Фізичне виховання, спорт і культура здоров'я у сучасному суспільстві: зб. наук. праць Волин. нац. ун-ту ім. Лесі Українки. Луцьк, 2012. № 4 (20). С. 473-477.

15. Савчук С. А. Аналіз стану соматичного здоров'я студентів вищого технічного навчального закладу. Фізичне виховання, спорт і культура здоров'я у сучасному суспільстві: зб. наук. праць Східноєвроп. нац. ун-ту ім. Лесі Українки. Луцьк, 2011. № 3. С. 79-82.

16. Сапожник О. А. Фізичний розвиток студенток навчального закладу. Фізичне виховання, сnорт, $i$ культура здоров 'я у сучасному суспільстві: зб. наук. праць Волин. нац. ун-ту ім. Лесі Українки. 2012. № 4. С. 330-334.

17. Сухарев А. Г. Двигательная активность и здоровье подрастающего поколения. Москва: Знание, 1976. 63 с.

18. Цьось А., Шевчук А., Касарда О. Рухова активність у мотиваційно-ціннісних орієнтаціях студентів. Фізичне виховання, спорт і культура здоров'я у сучасному суспільстві: зб. наук. праць Східноєвроп. нац. ун-ту ім. Лесі Українки. Луцьк, 2014. № 4 (28). С. 83-87.

19. Bergier B., Tsos A., Bergier J. Factors determining physical activity of Ukrainian students. Annals of Agricultural and Environmental Medicine. 2014. Vol. 21, Nr. 3. S. 613-616.

20. Byelikova N., Indyka S. Organization of Volunteer Health-saving Activity of Future Specialists in Physical Education and Sport. Фізичне виховання, спорт і культура здоров'я у сучасному суспільстві: зб. наук. праць Східноєвроп. нац. ун-т ім. Лесі Українки. Луцьк, 2016. №1 (33). С. 29-33.

21. Tsos A., Homych A., Sabirov O. The state of physical and psychological components of health in the quality of life of the university students. Człowiek $i$ Zdrowie. T. VII. Nr. 2. Państwowa Szkoła Wyższa, Biała Podlaska, 2013. C. 8-12.

22. Tsos A., Sushchenko L., Bielikova N., Indyka S. Influence of working out at home on the expansion of cardiovascular disease risk factors. Journal of Physical Education and Sport. 2016. Vol. 16(3). Art 159. P. 1008-1011.

23. Ulianytska N., Vadziuk S., Byelikova N., Indyka, S., Usova O. Violation of the Teenagers-Computer Users' Binocular Visionand Pecularitiesofits Restoration. Фізичне виховання, спорт $і$ культура здоров'я у сучасному суспільстві: зб. наук. праць Східноєвроп нац. ун-т ім. Лесі Українки. Луцьк, 2017. № 2 (38). С. $182-187$.

\section{References}

1. Andriichuk, O., Shevchuk, A., Samchuk, O., Khomych, A. (2015) Osoblyvosti fizychnoho y psykholohichnoho komponentiv zdorovia studentiv zalezhno vid yikhnikh navchalnykh dosiahnen [Features of the physical and psychological components of the health of students depending on their academic achievements]. Fizychne vykhovannia, sport i kultura zdorovia u suchasnomu suspilstvi: zb. nauk. prats Skhidnoievrop. nats. un-tu im. Lesi Ukrainky. Lutsk, no. 3 (31), 96-104.

2. Bielikova, N. O. (2014). Z dosvidu vykorystannia interaktyvnykh metodiv navchannia u profesiinii pidhotovtsi maibutnikh fakhivtsiv z fizychnoho vykhovannia ta sportu [From the experience of using interactive teaching methods in the training of future specialists in physical education and sports]. Suchasni informatsiini tekhnolohii ta innovatsiini metodyky navchannia $v$ pidhotovtsi fakhivtsiv: metodolohiia, teoriia, dosvid, problemy: zb. nauk. prats. Kyiv;Vinnytsia: TOV Planer, Vyp. 37, 348-353.

3. Dedeliuk, N. A, Kovalchuk, N. M., Vashchuk, L. M., Tomashchuk, O. H., Saniuk, V. I., Savchuk, S. A. (2018). Model orhanizatsii sportyvno-ozdorovchoi diialnosti studentiv vyshchykh navchalnykh zakladiv [Model of organization of sports and recreation activity for students of higher educational institutions]. Fizychne vykhovannia, sport i kultura zdorovia u suchasnomu suspilstvi: zb. nauk. pr. Skhidnoievrop. nats. un-tu im. Lesi Ukrainky. Lutsk, no. 1 (41), 29-35.

4. Zakhozhyi V. V., Sapozhnyk O. A. (2009). Dozuvannia fizychnykh navantazhen dlia samostiinykh zaniat fizychnymy vpravamy studentiv [Dosage of physical activity for individual exercises by physical exercises of students]. Fizychne vykhovannia, sport, i kultura zdorovia u suchasnomu suspilstvi: zb. nauk. pr. Volyn. nats. un-tu im. Lesi Ukrainky, no. 2 (6), 39-42.

5. Yvashchenko, L. Ya., Blahyi, A. L., Usachev, Yu. A. (2008). Prohrammyrovanye zaniatyi ozdorovytelnym fytnesom [Programming of health-improving fitness classes]. Kyiv: Nauk. Svyt, 198.

6. Indyka, S. Ya. (2015). Rol osvitnoi prohramy u reabilitatsii khvorykh pislia infarktu miokarda [The role of academic programs in the field of patients rehabilitation after myocardial infarction]. Naukovyi chasopys Nats. ped. un-tu imeni M. P. Drahomanova. - Seriia no. 15: Naukovo-pedahohichni problemy fizychnoi kultury (fizychna kultura $i$ sport): zb. nauk. pr. K.: Vyd-vo NPU im. M. P. Drahomanova, 2015. Seriia 15, Vyp. 3K2 (57). 15. $145-147$.

7. Krutsevych, T. Yu., Bezverkhnia, H.V. (2010). Rekreatsiia u fizychnii kulturi riznykh hrup naselennia [Recreation in the physical culture of different groups of the population]. K.: Olimpiiska l-ra, 248. 
8. Mytchyk, O. P., Sapozhnyk, O. A. (2011). Riven interesu do fizychnoi kultury y sportu v studentok VNZ [The level of interest in physical education and sports for university female 21-28. Fizychne vykhovannia, sport, $i$ kultura zdorovia u suchasnomu suspilstvi: zb. nauk. pr. Volyn. Nats. Un-tu im. Lesi Ukrainky, no. 1 (13), 40-43.

9. Michuda, Yu. P. (2002). Problemy vdoskonalennia mekhanizmu derzhavnoho upravlinnia sferoiu fizychnoi kultury i sportu $\mathrm{v}$ Ukraini [The problems of improving the mechanism of public administration in the sphere of physical culture and sports in Ukraine]. Zbirnyk naukovykh prats Volynskoho derzhavnoho universytetu. T.1. Lutsk, 26-28.

10. Muravov, Y. V. (1989). Ozdorovytelnye aspekty fyzycheskoi kultury i sporta [Health-improving aspects of physical culture and sports]. Kyev: Zdorovia, 124.

11. Navrotskyi, E., Pantik, V. (2013). Udoskonalennia sylovykh yakostei studentiv zasobamy atletychnoi himnastyky [Improvement of strength qualities of students by means of athletic gymnastics]. Fizychne vykhovannia, sport $i$ kultura zdorovia u suchasnomu suspilstvi: zb. nauk. prats. Lutsk, No. 2 (22). 47-51.

12. Pantik, V. V, Navrotsky. E. I. (2004). Vplyv systematychnykh zaniat fizychnymy vpravamy na systemy orhanizmu ta riven somatychnoho zdorovia liudyny [The influence of systematic physical exercises on body systems and the level of somatic human health]. Naukovyi visnyk Volynskoho Derzhavnoho Universytetu imeni Lesi Ukrainky. Lutsk, no. 4, 195-199.

13. Rovnii, A. S., Rovnii, V. A, Rovna, O. O. (2014). Fiziolohiia rukhovoi aktyvnosti [Physiology of motor activity]. Kh., 344.

14. Roda, O. B., Marionda, I. I. (2012). Tendentsii naukovykh doslidzhen sportsmenok v aspekti statevykh osoblyvostei [Trends of scientific researches of athletes in the aspect of sexual characteristics]. Fizychne vykhovannia, sport i kultura zdorovia u suchasnomu suspilstvi: zb. nauk. prats Volyn. Nats. Un-tu im. Lesi Ukrainky. Lutsk, no. 4 (20). 473-477.

15. Savchuk, S. A. (2011). Analiz stanu somatychnoho zdorovia studentiv vyshchoho tekhnichnoho navchalnoho zakladu [Analysis of the state of somatic health of students of a higher technical educational institution]. Fizychne vykhovannia, sport i kultura zdorovia u suchasnomu suspilstvi: zb. nauk. prats Skhidnoievrop. Nats. Un-tu im. Lesi Ukrainky. Lutsk, no. 3, 79-82.

16. Sapozhnik, O. A. (2012). Fizychnyi rozvytok studentok navchalnoho zakladu [Physical development of female students of an educational institution]. Fizychne vykhovannia, sport $i$ kultura zdorovia u suchasnomu suspilstvi: $\mathrm{zb}$. nauk. prats. Volyn. Nats. Un-tu im. Lesi Ukrainky. Lutsk, no. 4, 330-334.

17. Sukharev, A. H. (1976). Dvyhatelnaia aktyvnost y zdorove podrastaiushcheho pokolenyia [Moving activity and health of the younger generation]. M., Znanye, 63 .

18. Tsos, A., Shevchuk, A., Kasarda, O. (2014). Rukhova aktyvnist u motyvatsiino-tsinnisnykh oriientatsiiakh studentiv[Motor activity in student's motivational and value orientations]. Fizychne vykhovannia, sport $i$ kultura zdorovia u suchasnomu suspilstvi: zb. nauk. prats Skhidnoievrop. nats. un-tu im. Lesi Ukrainky. Lutsk, no. 4 (28), 83-87.

19. Bergier, B., Tsos, A., Bergier, J. (2014). Factors determining physical activity of Ukrainian students. Annals of Agricultural and Environmental Medicine. Vol. 21, no. 3, 613-616.

20. Byelikova N., Indyka S. (2016). Organization of Volunteer Health-saving Activity of Future Specialists in Physical Education and Sport. Fizychne vykhovannia, sport i kultura zdorovia u suchasnomu suspilstvi: zb. nauk. pr. Skhidnoievrop Nats. Un-t im. Lesi Ukrainky. Lutsk, no. 1 (33), 29-33.

22. Tsos, A., Sushchenko, L., Bielikova, N., Indyka, S. (2016). Influence of working out at home on the expansion of cardiovascular disease risk factors. Journal of Physical Education and Sport. Vol. 16(3), Art 159 pp. 1008-1011.

23. Ulianytska, N., Vadziuk, S., Byelikova, N., Indyka, S., Usova, O. (2017). Violation of the Teenagers-Computer Users' Binocular Visionand Pecularitiesofits Restoration. Fizychne vykhovannia, sport $i$ kultura zdorovia $u$ suchasnomu suspilstvi: zb. nauk. pr. Skhidnoievrop Nats. Un-t im. Lesi Ukrainky. Lutsk, no. 2 (38), $182-187$.

Стаття надійшла до редакції 24.11.2018 р. 